\title{
Development Problem Based Learning to Increase Skill Thinking High Levels
}

\author{
Alben Ambarita, Eka Liana, Chandra Ertikanto \\ University of Lampung, Bandar Lampung, Indonesia \\ Email: alben@unila.ac.id
}

How to cite this paper: Ambarita, A. Liana, E. and Ertikanto, C. (2018) Development Problem Based Learning to Increase Skill Thinking High Levels. Open Journal of Social Sciences, 6, 34-49. https://doi.org/10.4236/jss.2018.610004

Received: July 7, 2018

Accepted: October 19, 2018

Published: October 22, 2018

Copyright $\odot 2018$ by authors and Scientific Research Publishing Inc. This work is licensed under the Creative Commons Attribution International License (CC BY 4.0).

http://creativecommons.org/licenses/by/4.0/

(c) (i) Open Access

\begin{abstract}
This development research aims at the realization of the development of teaching materials based on Problem Based Learning to know the practicality and effectiveness of PBL teaching materials to improve high thinking skills of fourth grade students of elementary school. The research method used is research development (Development and Development) by using research steps according to Borg and Gall. The population in this research is the fourth grader of elementary school in one cluster of Kalianda District and the sample of the research is 28 fourth graders of elementary school. Data collection techniques in this study were conducted by the documentation, observation, expert validation sheet, questionnaire needs analysis, and tests. The results showed that the teaching materials developed can improve the ability of high-level thinking and learning outcomes of learners who have been analyzed using N-Gain.
\end{abstract}

\section{Keywords}

Development of Teaching Materials, Problem Based Learning Model, High Level Thinking

\section{Introduction}

Education is an important means of shaping and improving the quality of human resources. The development of natural resources for a nation has a role to fulfill and ensure the sustainability of various programs in it. Challenge and competition in this digital era require qualified human resources to be able to win competitions so quickly.

The quality of education in primary schools is currently in the category of concern that is indicated from low student learning outcomes, both nationally and internationally. In addition, the quality of teachers is also concerned that in- 
dicated from the low competent teachers, professional and pedagogic competence. This will impact on the low quality of learning in the classroom, which contribute to the low understanding of the students on the content or learning materials.

In the curriculum 2013 accommodates the adjustment of educational programs to the needs and potential in the region, refers to the national standard of education especially content standards and graduate competency standards. Meet the bill of the curriculum, in order to develop student potential, implemented through learning and support the availability of various tools, media, and good teaching materials. In order that, learning is expected to apply a scientific approach that emphasizes active student (student center) in learning.

In general, the existing conditions in primary school teaching materials support only use books provided by the government, which in quantity and quality less meet the curriculum bill. The author observed on September 12, 2017 in Public Elementary and Private Elementary School of Kalianda District of South Lampung Regency (SDN 1 Way Urang, Way Urang SDN, SDN 3 Way Urang, SDN Kedatan and SD Darul Quran), that the cluster has implemented the Curriculum 2013, but the learning process is still dominated by teachers (teacher center), less involving the participation of students to find the concept of learning. The findings, supported by interviews with guardians of class IV SDN 2 Way Urang, that the expected approach to the implementation of the 2013 curriculum has not been fully understood, even after training.

Another finding, obtained that the teaching materials used are the acquisition of the publisher, which is less meet the needs of students and the demands of the curriculum. This leads to less effective learning in developing the cognitive domain (conceptualization), affective spheres (learning attitudes), as well as high-level thinking skills (critical thinking and creative thinking) of students. The above facts are supported by data on the results of fourth grade students in SD Padi in 2016/2017 in the even semester.

Student involvement tends to be at the end of the meeting, which is doing the exercises in the student's book, regardless of the basic competency bill and the indicators formulated in the syllabus or the Lesson Plans (RPP).

The result of the analysis of learning needs through interviews and questionnaires of teachers in SD Gugus Padi, it is found that teachers need to apply approaches and learning models that support the demands of Curriculum 2013, which is generally applied starting in 2016/2017 for students of grade I and fourth grade students. In addition, it is necessary to improve the quality of learning with the availability of teaching materials that can make students active, orientate the learning models that involve students constructing learning materials through problem-based learning, project, discovery, and direct experience in student life.

Developed instructional materials, need to pay attention to the learning steps that are appropriate to the lesson ordered in the Curriculum 2013, by meeting 
the needs of students and utilizing the local environment as a source of learning. In addition, it is necessary to adjust the problem-based learning steps. That is, teaching materials not only meet the basic competency and indicator bills, but for students to think critically. The developed teaching materials also include activities involving students actively such as problem exercises, simple discussions and experiments. In addition to using instructional media in the form of instructional learning materials should be done using a learning model that can improve the effectiveness and solve problems. The teacher's creativity will determine the learning process of the students on integrated thematic learning. This need, can be met with the selection of problem-based learning model (Problem Based Learning), hereinafter abbreviated as PBL.

The PBL model is rooted in Jhon Dewey's belief in Abidin (2014: 158) [1] that teachers should teach by attracting students' natural instincts to investigate and create. Based on that view, it then develops into a problem-based learning model as the first thing to emerge during the learning process. The problem is presented as thoroughly as possible and students work with problems that require students to apply their knowledge and abilities according to the level of psychological maturity and learning ability. Implementation of PBL on integrated thematic learning, teachers' creativity will determine the learning activities of students on integrated thematic learning.

The reason for choosing the PBL learning model in this research is because the PBL model has deeper potential that can improve students' high thinking ability, able to deepen the students' understanding, pleasing the students in learning, develop the students' positive attitude, develop student leadership attitude, develop student's curiosity, improve student self-confidence. In accordance with the opinion of Jool (2015) [2] that the results of his research indicate that problem-based learning is an effective use of the model to improve the information literacy capabilities of learners.

PBL is used because it has some advantages that is a good enough technique to better understand the content of the lesson, can improve the effectiveness of student learning, and able to help students to understand the problem in real life. According to Fatade (2013) [3] recommends that the use of PBL as a strategy learning to improve learners' performance in cognitive and non-cognitive outcomes.

In accordance with the results of Sungur (2008) research [4], problem based learning creates an environment in which students 1) participate actively in the learning process, 2) take responsibility for their own learning, and 3) make learners better in management skills time and ability to define topics, access different resources, and evaluate the resourcefulness of resources. The Tilltiman (2013) [5] study has led to the conclusion that students who use PBL in a mathematical context gain more work levels and can help their classmates as compared to their counterparts in traditional classrooms.

The objectives of the research are 1) To produce appropriate PBL-based 
teaching materials to improve the thinking skills of fourth grade students of elementary school; 2) Describe the practicality of PBL teaching materials to improve high-order thinking skills of fourth grade students of elementary school; and 3) Describe the effectiveness of developing PBL teaching materials to improve high-order thinking skills in grade 4 elementary school students.

\section{Method}

The research method used is research development (Research and Development) by using research steps according to Borg and Gall (1983: 775) [6] consisting of 1) initial research and information gathering, 2) planning, 3) initial product format development, 4) preliminary trials, 5) product revision, 6) field trials, 7) product revisions, 8) field trials, 9) final product revisions, and 10) dissemination and implementation.

Initial information gathering includes measurement of needs, literature studies, small-scale research, and value-judgmental considerations. At this stage the researchers conducted observations and interviews with teachers and fourth graders at SD Gugus Padi. The learning process has been using the 2013 curriculum, but teachers still provide teaching materials formally and only based on existing teacher books and student books. The next step is the Literature study [7]. This study is a study to study the concept or theory related to the product to be developed (Sukmadinata, 2012: 184).

The population in this research is the fourth grader of elementary school in one group of Kalianda sub district which is Padi Padi which amounted to 133 people and sample amounted to 28 people. Field studies in this study were conducted at SDN 2 and 3 Way Urang. Instruments used in this field study were interviews conducted with classroom teachers, then analyzed textbooks related to the material, and requested data documentation of student learning outcomes.

A preliminary study was conducted to find out information that could be used to plan the product or to collect data about the condition of teaching material requirement analysis, curriculum analysis and material analysis as well as to analyze the Content Standards covering Core Competence and Basic Competence (KD) to design learning tools which became the reference in the development of teaching materials the theme of the beautiful diversity of my country. In addition to improving high-level thinking skills as well as related literature PBL model.

Data collection techniques in this study were conducted in 5 ways, namely: 1) observation is a technique of data collection by conducting observations on the ongoing activities with record-keeping; 2) Documentation, is any written statement natural, not reactive so easily found with content review techniques. In this study, this technique was used to obtain data on teachers, staff and elementary students, daily test scores and photographs during study time study; 3) The test is a tool or procedure used to know or measure skills, knowledge, attitudes, intelligence and ability or talent. In this study, the test used is post-test learning 
outcomes. This test contains problems from the problem-based learning process to see student learning outcomes; 4) Questionnaires used in this activity are expert validation questionnaires, user validation questionnaires are teachers and students. Questionnaires are used to determine the validity and validity of the instruments in the learning activities. Expert validation questionnaire filled by the validator in this case is the principal, while the user validation questionnaire is filled by the classroom teacher.

Technique of data analysis in research is instrument test, that is validity test, reliability, difficulty and differentiation which is used to test instrument of appraisal as correct measuring instrument. Test the hypothesis using student response questionnaire and correlation Product Moment.

\section{Research Result}

\subsection{Results of Needs Analysis}

Based on the preliminary study of information gathering conducted by direct observation in the field and performing wawacara directly with the fourth grade teacher in the Padi Cluster. Based on the observation result, it is found that SD Gugus Padi has been using Curriculum 2013. Furthermore, in terms of school facilities and infrastructure is sufficient, such as student study room there is a table of teachers, student tables, cabinets and blackboards. While the results of interviews with the fourth grade teacher, obtained that the student learning outcomes are still low has not reached the KKM, especially on the theme of Beautiful diversity in my country, Students can not understand the concept of the material being taught.

While the learning process and learning activities are still centered on the teacher and directly do the exercises without being given space to show the creativity and ability through discussion and achievement. It makes students less active in learning. The situation is also exacerbated by the lack of learning resources in the form of teaching materials for students, where one source of learning for 2 students. This adds to the lack of effective learning processes.

Based on the results of observation and questionnaire analysis of the need for teaching materials, the authors conclude that the need to develop teaching materials that can overcome the problems of learners. Therefore, the authors develop teaching materials based on PBL model.

\subsection{Results Planning and Product Design}

Planning is done by analyzing the results of previous information gathering. Where the authors do the analysis of thematic textbook needs in accordance with the circumstances of students in SD Gugus Padi, with attention to the characteristics, abilities and experience of students learning in the classroom, as well as students' cognitive development abilities, seeking information about making effective textbooks, identifying material concepts taught. Furthermore, the au- 
thors compile systematically the materials that will be taught in the research using the teaching materials of the theme berbagaai using PBL model, make the formulation of learning indicators that must be achieved by students based on $\mathrm{KI}$ and KD from the themes that have been determined in Curriculum 2013.

\subsection{Preparation of Teaching Materials}

Preparation of products the beginning of this instructional material is done by analyzing all data that has been obtained in the observation stage, both data at the stage of seeking information by interviewing the teacher directly in class IV or field study stage by looking directly at the school situation. Initial data analysis conducted at this stage is to determine the goals to be achieved by students after following the learning process. The thing done is the authors analyze the curriculum both $\mathrm{KI}$ and $\mathrm{KD}$ and themes and subtheme that will be used in the development of thematic materials for fourth graders in SD Gugus Padi.

Based on the results of interviews with fourth grade teachers, explained that the themes and subthemes that are still difficult to understand by the students in the learning process in Elementary School Padi is on the theme 7 is the Beautiful Diversity in my country special on subtheme 3 The beautiful unity and unity of my country. Also explained that in four subjects on the subtheme IPS, Bahasa Indonesia, Civics and SBdP, fourth graders in Elementary School Padi still difficult to understand learning on the theme 7 subtheme 3 .

After the curriculum analysis is done, the author then analyzed the situation directly in the field, based on the results of field studies that have been done in SD Gugus Padi. It was found that in SD Gugus Padi the learning process is still centered on the teacher without giving opportunity to the students to make the work and present it. Based on the student's learning style the author chose to use the PBL model with the help of teaching materials and thematic textbooks. In addition to viewing in terms of learning styles of fourth grade students in SD Gugus Padi, the authors also see the behavior or characteristics of students in Elementary School Padi have age 9 - 11 years, at this age is called concrete operational stage ( $7-11$ years) to think logically. New abilities include operations, thinking no longer concentration but concentration, and problem solving not limited by keegocentrisa. Students in Elementary School Padi have good communicative kempun to dig information. It is suitable to be applied with teaching materials of the beautiful theme of Diversity Negeriku using model Problem Based Learning because students can use the ability to dig information to solve the problem.

The next step is to develop a benchmark reference test. The test will be done using the description. The author only makes the instrument grid problem on the theme 7. The beauty of diversity Negeriku Subtheme 3 because in this subject students still have difficulty visible from the KKM value of students who are still low. After making the grid problem, then the next make a description of the problem that adapted to the lattice problem. Then, the matter was consulted to 
the mentor and tested to the students in SDN 3 Way Urang to know the validity, reliability of the matter. Do not stop there, the next step the authors do a test questionnaire student response to teaching materials.

The author then designed the learning activities using the PBL model. The steps of learning activities are as follows; 1) The teacher explains the learning objectives; 2) The teacher divides the students into 4 - 5 groups consisting of 4 5 people; 3) The teacher distributes thematic materials to the students; 4) Teacher gives problem to student that exist in thematic teaching materials; 5) The teacher guides the students to define the problem; 6) Students formulate hypotheses; 7) Students discuss and determine alternative problem solving; 8) Students present the results of problem solving; 9) Teachers together with students reflect on and evaluate the investigations they undertake and the learning processes that have been implemented.

After the design of learning activities completed, the author then wrote the device that begins with the selection of research textbook development format. Steps for developing teaching materials include writing, adapting, editing instructional materials designed. This step is done by collecting the writing material in accordance with the theme 7 on subtheme 3 in the form of concept. Problem-solving tasks to be completed, drawings that support materials for the making of thematic materials, examples of problems in accordance with sub-theme 3 .

\subsection{Experiments Results of Materials and Media}

The assessment of thematic teaching materials and the medium of thematic materials using the model of PBL done by Mrs. Dr. Dwi Yulianti, M.Pd, she is a lecturer at Lampung University. The initial product that has been finished compilation is tested by material experts and media test 2 times. In the first expert test phase on January 19, 2018 in terms of learning materials by Mr. Darsono, M. Pd that need to be improved are as follows; 1) PBL is a problem-based learning model; 2) The material expert suggests that problems in the material should be aligned with sub-theme 3 ; 3 ) the initial product of the author of the displayed problem is not yet compatible with subtheme 3;4) Furthermore, the presented image must be genuine about the diversity that exist in the community environment, because previously in the initial product of the researcher the image contained in the teaching materials is a cartoon or animated image.

As for the teaching materials media design he suggested as follows, 1) on the cover page adjust the size of the letters; 2) right and left margins adjusted; and 3) images adjusted to the subtheme 3 The beautiful unity and unity of my country. The initial cover on the product that researchers make is still very ordinary only consists of two colors and margins are still irregular, as well as images that have not been in accordance with the theme chosen by the author, this makes the appearance of teaching materials that researchers stacking less interesting for readers. 
The second material expert test was conducted on February 9, 2018 which must be improved is the learning path of the letters adjusted with the learning step on the PBL model, it is suggested because previously the initial step in the product that the researcher stacked has not been in accordance with the steps in the PBL model and the last is about the learning objectives made at each meeting. While for the media design he suggested for the teaching materials products should be named developers, so that the product is made known who the compiler, in addition to the instructions of use must also be improved in order to be more easily understood by the reader. Furthermore, the last suggestion given by Dr. Dwi Yulianti, M.Pd is not allowed to use many variasai letters.

\subsection{Early Field Trial Results (Preliminary Field Testing)}

Procedure textbook development does not just stop on the validity of the test material experts and media experts but continues on a limited product test. A limited product trial was conducted at SDN 2 Way Urang on January 22, 2018 and February 12, 2018, in a limited test also tested the validity and reliability of the questions that will be used to measure the completeness of student learning outcomes both pres-test and post-test, test results validity and reliability questions can be sorted on the attachment.

There are differences in learning outcomes before using textbooks using the PBL model with after using the PBL teaching materials. The increase that occurs before and after learning is calculated by the N-Gain formula, which is as follows: Gain is the difference between the posttest and pretest values, the gain indicates an increase in understanding or mastery of the students' concepts after the teacher's learning. To avoid the conclusions of the research bias, because at the pretest value of the two research groups have different use normality test.

The advantages of using models to improve high-order thinking skills are reviewed based on the ratio of normalized gain ( $\mathrm{N}$-gain) values, between the experimental group and the control group. Table 1 is the result of score calculations Pre-Test and Post-Test.

Based on the hypothesis test, the result of N-Gain calculation is 0.35 with

Table 1. Score calculations Pre-Test and Post-Test.

\begin{tabular}{|c|c|c|c|c|c|}
\hline \multirow{2}{*}{ No } & \multirow{2}{*}{ Indicator } & \multicolumn{3}{|c|}{ Test Score } & \multirow{2}{*}{ Criteria } \\
\hline & & Pre-Test & Post-Test & N-Gain & \\
\hline 1 & Number of Students & 28 & 28 & \multirow{7}{*}{0.35} & \multirow{7}{*}{ Medium } \\
\hline 2 & Total Value & 1530 & 1985 & & \\
\hline 3 & Average Value & 55 & 71 & & \\
\hline & & & & & \\
\hline 4 & Highest Score & 70 & 100 & & \\
\hline 5 & Lowest Score & 30 & 35 & & \\
\hline 6 & Completeness Level & $25 \%$ & $79 \%$ & & \\
\hline
\end{tabular}


medium category and the students reaching KKM score of 79\% (22 students), the theme materials The beautiful diversity in my country using PBL model effectively used in class IV SDN 3 Way Urang, Further teaching materials will be tested widely in other schools in the Paddy Group.

Based on Table 2 in on the questionnaire of students' responses to teaching materials using the PBL model, obtained an average of 71 points indicates that the teaching materials are in good category.

In addition to questionnaire responses of students to teaching materials theme Beautifulness Diversity Negeriku using PBL model, the following is the result of teacher instruments on teaching materials. In his assessment of textbooks created by the author, SDN 3 Way Urang teacher, Ibu Astuti, S.Pd. gave a score of 80. This shows that the theme of the theme of The Beautifulness of Diversity Negeriku usingmodel Problem Based Learning, valid and effective use in learning process for expanded test.

\subsection{Field Trial Results Main (Main Field Testing)}

After the test phase the product is limited and corrected the deficiencies that still exist in the product's first teaching materials, further expanded test products. The trial of extended product usage was done in the fourth grade of SDN 3 Way Urang, and SDN 2 Way Urang. In the expanded trial, conducted pre-test and post-test were using the PBL model. The results of pre-test and post-test were analyzed to know the difference of learning result both before and after using teaching materials using model Problem Based Learning in class IV in Paddy Group. The extended product trial was conducted at SDN 2 Way Urang, and for the second extended trial was conducted at SD Way 3 Urang.

\subsection{Class IV SDN 3 Way Urang (Product Trial Expanded I)}

The first expanded product trial was conducted at SD Way 3 Urang on February 12, 2018 for pre-test and February 17, 2018 for post-test. The results of pre-test and post-test on product trial expanded I at SDN 3 Way Urang. There is a difference between learning outcomes before and after using theme materials

Table 2. Score in class IV SDN 3 way urang.

\begin{tabular}{ccccc}
\hline Interval & Lower Boundary-Upper Limit & $\mathrm{F}$ & $\mathrm{X}$ & $\mathrm{F} * \mathrm{X}$ \\
\hline $60-63$ & $59.5-63.5$ & 3 & 61 & 185 \\
$64-67$ & $63.5-67.5$ & 5 & 65 & 328 \\
$68-71$ & $67.5-71.5$ & 6 & 69 & 417 \\
$72-75$ & $71.5-75.5$ & 6 & 73 & 441 \\
$76-79$ & $75.5-79.5$ & 7 & 77 & 543 \\
$80-83$ & $79.5-83.5$ & 1 & 81 & 82 \\
& Total & 28 & 426 & 1996 \\
& Average & & & 71 \\
\hline
\end{tabular}


The beauty of diversity in my country using the PBL model. The increase that occurs before and after learning is calculated by N-Gain, as shown in Table 3.

As shown in Table 4: based on the results of the hypothesis N-Gain of 0.32 with medium category and students achieving KKM score of percentage percentage Pre-Test of 46\% (13 students), percentage Post-Test of $86 \%$ (24 students), teaching materials theme Beautiful diversity in my country using model PBL effectively used in class IV SDN 3 Way Urang.

\subsection{Class IV SDN 2 Way Urang (Product Trial Expanded II)}

The second expanded product trial was conducted at SDN 2 Way Urang on 19 February 2018 pre-test and February 24, 2018 post-test was conducted on the lesson. There is a difference between learning outcomes before and after using theme materials. The beauty of diversity in my country uses the PBL model. The increase that occurs before and after learning is calculated by N-Gain, as shown in Table 5.

Table 3. Learning outcomes in SDN 3 Way Urang.

\begin{tabular}{cccccc}
\hline \multirow{2}{*}{ No } & Indicator & \multicolumn{3}{c}{ Value Test } & \multirow{2}{*}{ Criteria } \\
\cline { 2 - 4 } & & Pre-test & Post-Test & N-Gain & \\
\hline 1 & Number of Students & 28 & 28 & & \\
2 & Total Value & 1594 & 1980 & & \\
3 & Average Score & 57 & 73 & & Medium \\
4 & High Score & 70 & 90 & 0.32 & \\
5 & Lowest Score & 30 & 35 & & \\
6 & Completeness Level & $46 \%$ & $86 \%$ & & \\
\hline
\end{tabular}

Table 4. Category of learning outcomes.

\begin{tabular}{cccl}
\hline No & Name School & N-Gain & Category \\
\hline 1 & SDN 3 Way Urang & 0.32 & Medium \\
2 & SDN 2 Way Urang & 0.33 & Medium \\
\hline
\end{tabular}

Table 5. Learning outcomes in SDN 2 way urang.

\begin{tabular}{lccccc}
\hline \multirow{2}{*}{ No } & Indicator & \multicolumn{3}{c}{ Value Test } & \multirow{2}{*}{ Criteria } \\
\cline { 3 - 4 } & & Pre-Test & Post-Test & N-Gain & \\
\hline 1 & Number of Students & 28 & 28 & \\
2 & Total Value & 1530 & 1985 & \\
3 & Average Value & 55 & 71 & \multirow{2}{*}{ Medium } \\
4 & High Score & 70 & 90 & & \\
5 & Lowest Score & 30 & 35 & & \\
6 & Completeness & $25 \%$ & $79 \%$ & & \\
\hline
\end{tabular}


Based on the results of the N-Gain 0.33 hypothesis with medium category and students achieving the average percentage pre-test of $25 \%$ (18 students), percentage post-test of $79 \%$ (21 students), the theme of the subject The beauty of diversity in my country using PBL model effectively used in class IV SDN 2 Way Urang. Here are the results of $\mathrm{N}$-gain calculations performed in the Paddy Cluster.

Results of PBL-Based Teaching Material Development Test Eligible for Improving High-Level Thinking Skills

The first hypothesis test is to use validity tests with material experts and media experts. The results of the calculation scores obtained are as shown in Figure 1.

Based on the histogram known that the validation of the material expert is 82 and the validation score of experts 95 . The validation results can show the realization of teaching materials based on PBL model that can improve the ability of High-Level Thinking of fourth grade students. This is in accordance with the opinion of Safrina and Saminan (2015) [8] which shows that the result of study of Problem Model Based model influences the understanding of the concept to be better and also according to Belland (2009) [9] research results show that each group member filled a unique manager role group, task guidance, and player duties and help each other overcome individual difficulties. The results of the study indicate that the main groups have the potential to be effectively involved in PBLs, and that PBLs can improve students' motivational and social confidence with the special needs.

\subsection{PBL Teaching Practice Test Results to Improve High-Level Thinking Skills}

The second hypothesis test is using a student response questionnaire. Based on the results obtained from the questionnaire the average student response got a student's questionnaire result was 71.2. Based on the qualification of learning implementation, PBL teaching materials used to improve the thinking skills of high grade students of elementary school grade IV enough.

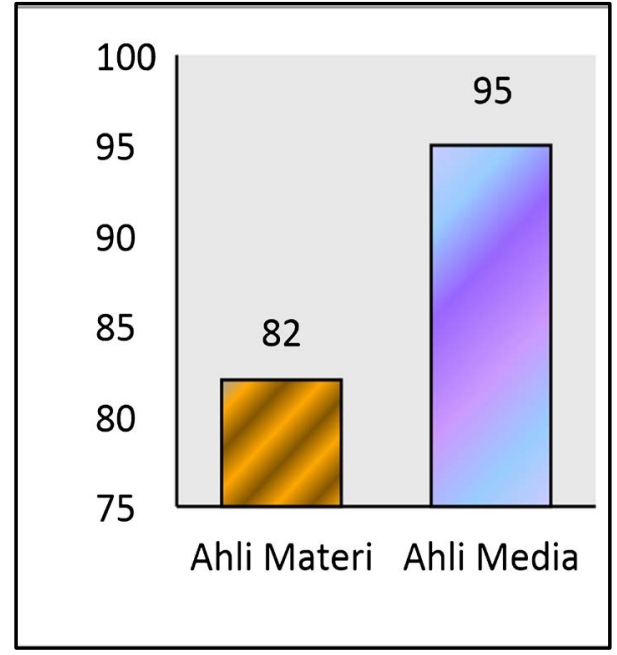

Figure 1. Calculation scores obtained. 
This is in accordance with the results of research from Drake (2009) [10] that the application of problem-based learning in improving the mastery of knowledge content (knowladge of content), self-image as a scientist (stereolypleai intages of scientists), the use of time effectively (team-on-task), and transfer (of problem solving skills transfer of problem solving skills).

\subsection{Test Results of Practicality of PBL Teaching Materials to Improve High-Level Thinking Skills}

Testing the second hypothesis is to use a student response questionnaire. Based on the results obtained from the questionnaire the average student response got a student's questionnaire result was 71.2. Based on the qualification of learning implementation, PBL teaching materials used to improve the thinking skills of high grade students of elementary school grade IV enough.

This is in accordance with the results of research from Drake (2009) [10] that the application of problem-based learning in improving the mastery of knowledge content (knowladge of content), self-image as a scientist (stereolypleai intages of scientists), the use of time effectively (team-on-task), and transfer of problem solving skills (transfer of problem solving skills).

\subsection{Effectiveness Test Result of PBL Teaching Material Development to Improve Higher-Order Thinking Skills}

The results of the calculation shows that the effectiveness of the use of textbooks can be seen from differences in student learning outcomes before using the teaching materials and after using the teaching materials. Here is the percentage of improvement in the results of fourth grade students in the Paddy Pad before and after using the theme materials. The beauty of diversity in my country using the PBL model, as shown in Figure 2.

Based on the above diagram shows the increase in student learning outcomes fourth grade SDN Gugus Padi after using the theme materials Beautiful diversity

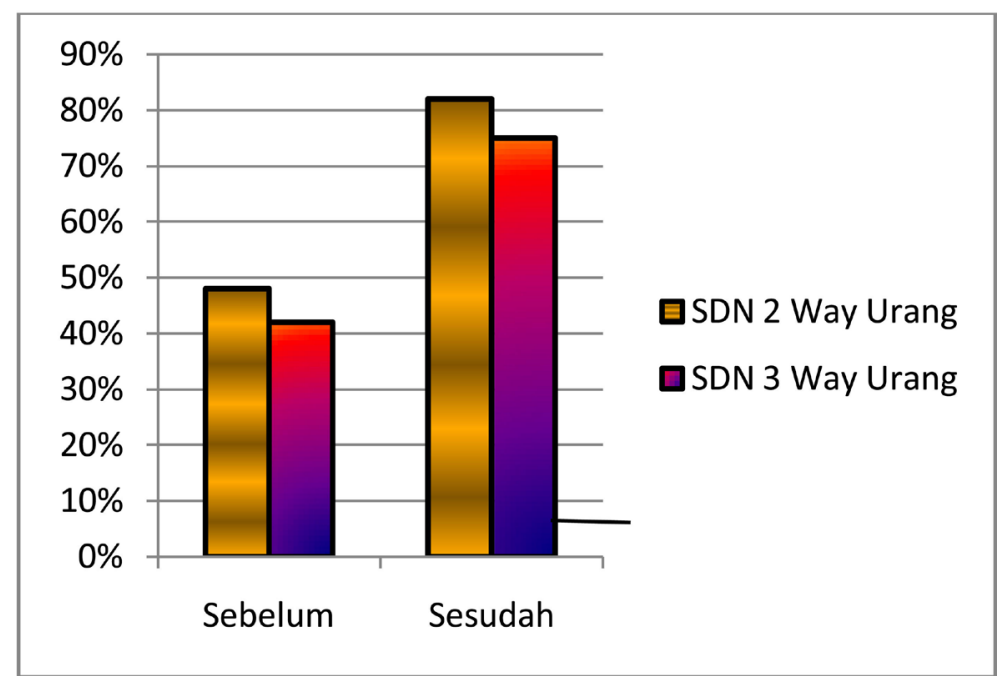

Figure 2. Diversity using The PBL model. 
in my country using a model of Problem Based Learning developed by the author. Before using teaching materials, the percentage of SDN 3 Way Urang learning result was only $46 \%$ of students who achieved KKM score after using teaching materials increased to $86 \%$ according to the attachment of page 156 . So also on SDN 2 Way Urang before using the teaching materials the percentage of learning result completeness is only $25 \%$ and after using textbook increased to $79 \%$. The effectiveness of teaching materials development results can also be seen also from the average increase in learning outcomes and completeness of student learning outcomes calculated using N-Gain. The average completeness of the learning outcomes of SDN 3 Way Urang students is 57 with N-Gain of 0.32 medium category according to the attachment of page 156, for SDN 2 Way the average learning result of the students as a whole is 71 with $\mathrm{N}$-Gain 0.33 medium category.

It shows that the theme of the theme of Beautiful Diversity in my country using the model of Problem Based Learning developed by the author effectively used in elementary schools in the Paddy Pad especially on subtheme 3 Beautiful Unity Unity Negeriku.

\section{Discussion}

\subsection{Development of PBL Model Based Materials}

This research is a development research, development is done by analyzing data of observation result by writer at SD in Padi Cluster. It is found that in the learning process the teacher does not use variation of learning model, less textbook and low learning result. Based on the data analysis it is expanded that the low learning outcomes of students in SD Gugus Padi lies in the theme of Beautiful Diversity in my country especially on subtheme 3. Therefore development is done by the authors of teaching materials. The theme of Diversity in my country for grade 4 students of Primary School.

PBL was chosen by the author as the model used because the PBL model asks the students to learn to solve the problems according to their daily life, both independently and in groups which will make students' social attitude better. Development is done not only limited to the use of PBL model only, but also choose KI and KD according to needed and characteristic of fourth grader of SD Padung Padi and also the applicable curriculum.

Statement in accordance with the opinion expressed by Fattade (2011) which that in learning PBL can improve the performance of learners. Because in this study refers to the curriculum 2013, the material presented in teaching materials based on a predetermined theme.

The development of this textbook the author also pay attention to various other things that must exist as a provision in the manufacture of teaching materials, such as teaching materials are prepared based on the applicable curriculum, because the SD in Gugus Padi using Curriculum 2013, the authors also compiled this resource based on Curriculum 2013. Furthermore, in the prepara- 
tion of teaching materials should also consider the approach used, because the teaching materials are made using Curriculum 2013. Then the approach used is a scientific approach. Where the learning process must touch three aspects of attitude, knowledge, and skills. In addition, teaching materials should also present facts that are appropriate to the state of society. The teaching materials have integrity with other disciplines.

Preparation of teaching materials conducted by the author in accordance with the opinion Komarudin (2016) [11]: the results show that teachers identify activities in growing skills and provide support for exploration activities in conducting experiments among students to provide opportunities for students to think, learn and learn.

Once the preparation of this resource is also in line with Belland's (2009) opinion: the results show that each group member is filled with a unique manager of group roles, task guidance providers, and player tasks and helps each other overcome individual difficulties. The results showed that the main groups have the potential to be effectively involved in problem-based learning, and that problem-based learning can improve students' motivational and social self-confidence. The development of teaching materials conducted by the authors in their research is in accordance with the applicable curriculum 2013, as well as the selection of models in the development of teaching materials is also in accordance PBL model to make students learn to solve problems that exist in the daily life of the preparation. Gives a clear picture of cohesiveness with other disciplines. And it has touched three areas that must exist in the curriculum of 2013, namely attitude, knowledge and skills.

\subsection{Practicality of Teaching Materials}

The practicality of teaching materials can be seen from students' questionnaire responses conducted at SD Way 3 Urang class IV involving 28 students. Based on the results obtained from the questionnaire the average student response got a student's questionnaire result was 71.2. Based on the qualification of learning implementation, PBL teaching materials used to improve the thinking skills of high grade students of elementary school grade IV enough.

\subsection{The Effectiveness of Teaching Materials}

The effectiveness of textbook theme of the various beautiful diversity of my country using the PBL model to improve students' high-order thinking can be seen from the results of fourth grade students of SD Gugus Padi after using the textbook. Before using the teaching materials, student learning outcomes in Elementary School Padi still low. The average student who passed the KKM was just under 10. After using the teaching materials the students' learning outcomes experienced a significant improvement. Completeness of student learning outcomes on the theme 7 . The beauty of diversity in my country subtheme 3 . The beautiful unity and unity of my country above 15 children. Except from the im- 
provement of learning outcomes that determine the effectiveness of teaching materials there are some things that become the characteristics of good and effective materials used, that is according Trianto (2013: 165-166) [12] teaching materials should stimulate students to be active, create a wearing learning style, provide holistic (thematic) knowledge and the last is to provide hands-on experience with students.

Teaching materials developed by the authors using the PBL model, it is sure that the teaching material is able to meet the characteristics that must exist in the teaching materials. There's characteristics in the implementation of teaching materials developed is the authors are able to make students active and thinking high level in learning both in groups and individuals, able to make learning more fun because students are given space to exchange ideas in solving problems and given a direct opportunity to seek good information in the classroom, go to the library and ask directly to the fourth grade teacher. This is proof that the use of textbook theme of my country's diversity using the PBL model effectively used in fourth graders Elementary School Padi.

\section{Conclusion}

Based on the results of research development of teaching materials theme Beautiful diversity in my country using the model of PBL in class IV in Elementary School Padi can be summed up as follows; 1) teaching materials theme Beautiful Diversity in my country using PBL model developed based on requirement analysis, media expert's judgment, material expert and student response expressed feasible to be used as instructional material in learning process fourth grader of SD Kaliug Padi District Kalianda in even semester of lesson year $2017 / 2018 ; 2$ ), the item should be able to measure the practicality of teaching materials according to the learning objectives. This principle should refer to the learning objectives that exist in each learning activity. Taxonomy of educational goals by Bloom in the high-level thinking cognitive domain, C4 (Analyze), C5 (Evaluate), and C6 (Creating). Before using the teaching materials, student learning outcomes in Elementary School Padi still low. The average student who passed the KKM was just under 10; and 3) teaching materials theme Beautiful Diversity in my country using the model of PBL produced effectively is used in the learning process to improve high thinking skills level of students in fourth grade elementary school Padaka Padi District. It is used with the increase of fourth grade students' learning result of SD Padi Padi, especially on the theme of Beautiful Diversity in my country, sub theme 7.

\section{Conflicts of Interest}

The authors declare no conflicts of interest regarding the publication of this paper.

\section{References}

[1] Abidin, Y. (2014) Desain Sistem Pembelajaran dalam Konteks Kurikulum. PT Refi- 
ka Aditama, Bandung.

[2] Jool, K.H. and Park, N.H.H. (2015) e-PBL Model Development for Computer Learning System. International Journal of Multimedia and Ubiquitous Engineering, 3,3 .

[3] Fatade, A.O. (2013) Effect Of PBL. On Senior Second Students' Achivement I Futher Mathematics. Acta Didactica Napocensia, 6, 28-44.

[4] Sungur, S. and Cereren, T. (2006) Effects of Problem-Based Learning And Traditional Instruction On Self-Regulated Learning. The Journal of Education Research, 99, 307-320. https://doi.org/10.3200/JOER.99.5.307-320

[5] Daniel, T. (2013) Implication of Problem Based Learning (PBL) in Elementary School upon the K-12 Engineering Education Pipeline. American Society for Engineering Education, 23, 32-43.

[6] Walter, B.D., Gall, J.P. and Gall, M.D. (1983) Educational Research an Introduction. Perason Education, Inc., Boston.

[7] Sukmadinata (2012) Metode Penelitian Pendidikan. PT Remaja Rosdakarya, Bandung.

[8] Safrina and Saminan (2015) Pengaruh Pembelajaran Model Problem Based Menunjukkan bahwa penerapan model PBL mempengaruhi pemahaman konsep menjadi lebih baik. Tersedia dalam Jurnal JIP. International Multidisciplinary Journal, 3, 1-12.

[9] Belland, B.R. (2009) Inclusion and Problem-Based Learning: Roles of Student in a Mixed-Ability Group. RMLE Online, 32, 1-19. https://doi.org/10.1080/19404476.2009.11462062

[10] Drake and Long, D. (2009) Rebecc's in the Dark a Rebecca's in the Dark: A Comparative Study of Problem-Based Learning and Direct Instruction/Experiential Learning in Two 4th-Grade Classrooms. Journal of Elementary Science Education, 21, 1-6. https://doi.org/10.1007/BF03174712

[11] Komarudin (2016) Inculcation of Higher Order Thinking Skill (HOTS) in Arabic Language Teaching at Malaysian Primary School. Scientific Research Publishing, 7, 307-314. https://doi.org/10.4236/ce.2016.72030

[12] Trianto (2013) Mendesain Model Pembelajaran Inovatif Progresif: KonsepLandasan, dan Implementsi pada Kurikulum Satuan Pendidikan (KTSP) Jakarta: Kencana Prenada Media Group. Journal Education Research, 2. 